\title{
Highbush Blueberry Breeders
}

\author{
James F. Hancock \\ Department of Horticulture, Michigan State University, East Lansing, MI 48824
}

Three men have been at the center of blueberry breeding: Frederick R. Coville, George M. Darrow, and Arlen Draper. Their leadership spanned almost a century, with Coville being active from 1908 to 1937, Darrow taking the mantel from 1938 to 1958 and Draper continuing from 1965 to the present. Other blueberry breeders have had significant independent programs, but these three men have led the way.

\section{FREDERICK COVILLE}

Frederick Coville (1867-1937) was the person responsible for domesticating the highbush blueberry, Vaccinium corymbosum (Fig. 1). He conducted the fundamental life history studies on how to propagate, grow and pollinate the highbush blueberry. He collected the first significant wild germplasm of Vaccinium corymbosum from across the northeastern U.S. with the help of Elizabeth White, and he was the first blueberry breeder.

Coville began his blueberry crosses in 1909 and, until his untimely death in 1937 , he evaluated 68,000 progeny and left another 30,000 seeds for others to sort through. A testimony to the greatness of his efforts is in the fact that $75 \%$ of the blueberry acreage in the 1990 s was composed of his hybrids (Mainland, 1998). Out of the top 10 cultivars, seven were developed by him including 'Bluecrop' (1), 'Jersey' (2), 'Weymouth' (3), 'Croatan' (4), 'Blueray' (5), 'Rubel' (7), and 'Berkeley' (8).

T.H. Kearney wrote of Coville in the 1937 U.S. Department of Agriculture (USDA) Yearbook of Agriculture, "Dr. Coville had a host of friends in all walks of life, to whom he was a patient and kindly counselor. Because

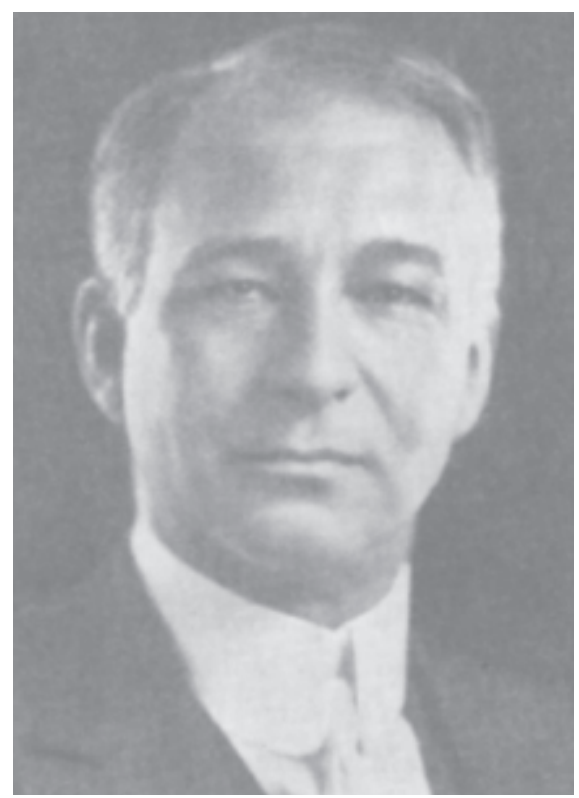

Fig. 1. Frederick Coville. of his reputation for sturdy good sense, people sought his advice, and he never begrudged for this purpose time that he could ill spare for his many occupations.......... No one who had the privilege to be in the field with him, could fail to be impressed by his keenness of observation and his constant appreciation of the beauty and human appeal as well as the scientific interest in plants."

\section{GEORGE DARROW}

George Darrow (1889-1983) had been at the USDA for 20 years when he took over Coville's breeding program (Fig. 2). Probably his most significant accomplishment was the development of an extensive collaborative network. He interacted with at least 10 agricultural experiment station scientists in Florida (R. Sharpe), Georgia(W.T. Brightwell), Maine (L. Whitten and R. M. Bailey), Michigan (S. Johnston), North Carolina (E.B. Morrow and G.J. Galletta) and New Jersey (J.N. Moore). He also collaborated with a number of private growers including S. Rose (Connecticut), J.H. Alexander (Massachusetts), A. Elliott (Michigan), and the Galletta brothers (New Jersey). His collaborations were at all levels from simple letters of encouragement, shared parents, site visitations and the distribution of huge numbers of seedlings. From 1946 to 1961, he sent almost 200,000 hybrids to at least 10 cooperators. His work with Ralph Sharpe in Florida built the framework for the southern highbush, and his collaboration with Tom Brightwell in Georgia lead to the first really fine rabbiteye cultivars.

Darrow was also intensely interested in the in the crossability and species relationships of the North American Vaccinium. Working with W.H. Camp, he made numerous interspecific

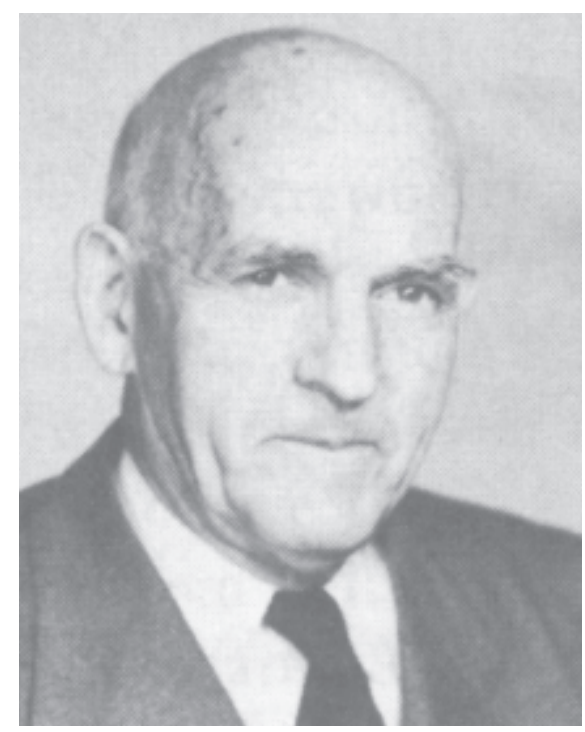

Fig. 2. George Darrow. crosses, in an attempt to understand the taxonomy of the cluster fruited blueberries. $\mathrm{He}$ felt this information would be pivotal to the effective use of wild germplasm in breeding. In an address to the North American Blueberries Growers Convention in 1966, Darrow suggested that "Coville laid the foundations of an industry. He seemed, however, almost afraid of two things: 1) of cooperation with experiment station directors and 2) of making a classification of the species of blueberries, even though a systematic botanist himself." Clearly, Darrow had decided to go a different path.

An excellent summary of Darrow as a man was provided by John R. Magness in a dedication written for the Advances in Fruit Breeding (1975), "Why has Darrow's work been so successful? With a firm foundation in genetics, he was an all around plantsman, a keen observer in every facet of the plant and its environment......Dr. Darrow's generosity and unselfishness have led to the willingness on the part of cooperators in all parts of the US to work with him. He has shared material freely, and has been as unbiased in evaluating the work and products of others as in evaluating his own material.....Through the years, his optimism and enthusiasm have been an inspiration to many young breeders, as well as his peers."

\section{ARLEN DRAPER}

Arlen Draper (born in 1930) took over the highbush breeding program of the U.S. Department of Agriculture (USDA) after it had been managed a few years by R.J. Knight and J.N. Moore(Fig. 3). He maintained and strengthened Darrow's collaborative network, by moving even deeper into the south without ignoring the north. Arlen interacted widely with most other blueberry scientists and in many cases provided them with big brown boxes of seedlings and elite selections. He worked with numerous agricultural experiment scientists including: J. Moore (Arkansas), R. Sharpe and W. Sherman (Florida), W. T. Brightwell and M. Austin (Georgia), J. Hancock (Michigan), P. Hepler (Massachusetts), L.F. Hough, G. Jelenkovic, and N. Vorsa (New Jersey) and G.J. Galletta and J. Ballington (North Carolina). He also worked closely with the private growers Duke Galletta(New Jersey), Arthur Elliott(Michigan and Florida), and John Nelson of the Michigan Blueberry Growers Association. The Gallettas, in particular, spent countless hours raising and caring for his hybrid populations and advanced selections.

Perhaps Arlen's most valuable contribution was his prodigious use of the native blueberry germplasm. He took interspecies hybridization to a fine art. Working with Don Scott and Gene Galletta, Draper used several different strategies to incorporate the genes of native species into the 


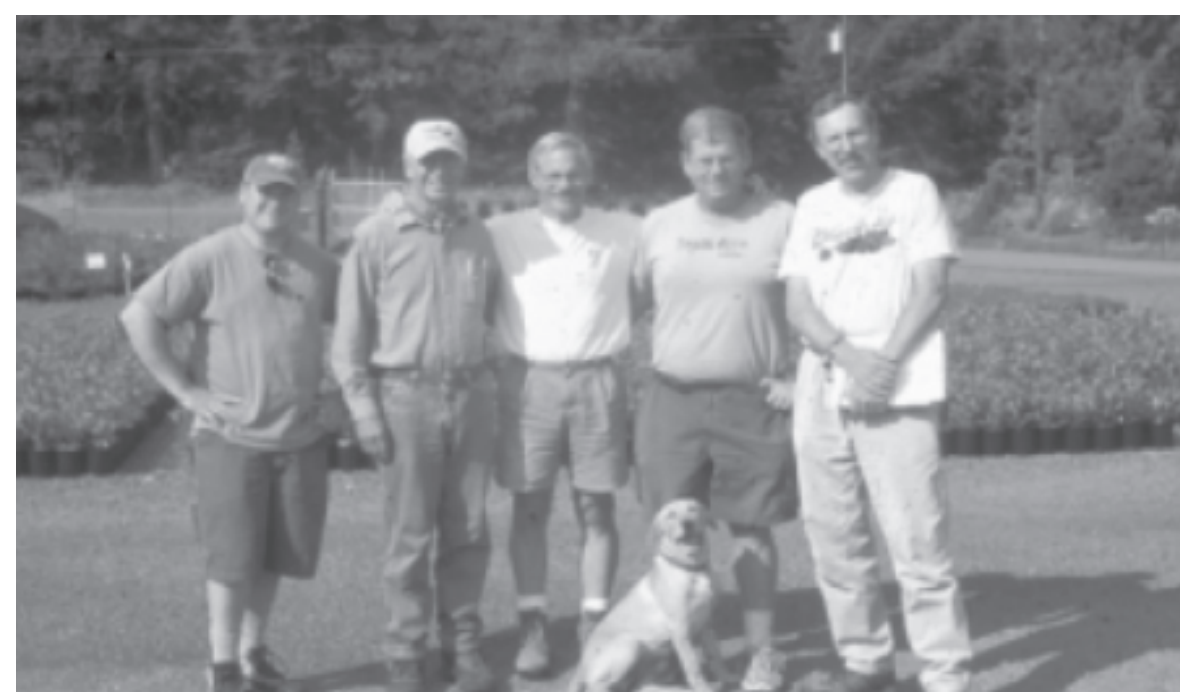

Fig. 3. (left to right) Brian Caster, Arlen Draper, Jim Hancock, Chad Finn, and David Brazelton.

cultivated highbush background. He produced interspecific tetraploid hybrids of $V$. myrsinites $\times V$. angustifolium that could be directly crossed with highbush. He colchicine-doubled diploid hybrids of $V$. myrtilloides $\times V$. corymbosum and then crossed this hybrid with $V$. corymbosum. $\mathrm{He}$ also generated many hybrids of diploid and polyploid species, and the most fertile ones were used as breeding parents. He crossed $V$. darrowi $\times$ V.corymbosum and obtained tetraploid hybrids that were completely interfertile with highbush types. The successful hybrid US 75 (Fla 4B $\times$ 'Bluecrop'), is an important source of low chilling requirement in a number of southern highbush cultivars.

Because of Arlen's work, most of the highbush types now being released are really complex hybrids. Examples of Draper's gene mixing wizardry include 'O'Neal' which contains genes from the four species (V. corymbosum, V. darrowi, V. ashei, and V. angustifolium) and 'Sierra', which possesses the genes of five species ( $V$. corymbosum, $V$. darrowi, $V$. ashei, $V$. constablaei, and $V$. angustifolium). Perhaps the most amazing example of his gene blending is 'Biloxi' which not only contains the genes from five species ( $V$. corymbosum, $V$. darrowi, $V$. ashei, V. atrococcum, and $V$. angustifolium), but also has more non- $V$. corymbosum than $V$. corymbosum genes in its genome.

When I think about Arlen's accomplishments, I can not help but chuckle at one of his comments to me one day, about how Sam Vander Kloet had destroyed his career during one of those times when the USDA was directing its scientists to be more basic. Sam is the taxonomist who published a paper that lumped all the highbush blueberry species of Camp into one. Arlen stated that with the publication of one manuscript, he was no longer making wide species crosses but instead was working within a single species. This changed him from a basic scientist pushing the boundaries of interspecies relationships into a common plant breeder. Of course Arlen was kidding, but it does point out how interconnected we really are.

The late Gene Galletta described Arlen Draper particularly well in our co-authored dedication to him in the 1995 Plant Breeding Reviews (vol. 13) He wrote, "Not only has Draper's imaginative use of blueberry germplasm attracted followers, but his unfailing enthusiasm and genuinely warm personality have made him a welcome and influential cooperator all over the world.......His cooperators characterize Draper as being a quiet behind the scenes facilitator who never sought credit or attention. This in addition to their general assessment of him as the world's foremost blueberry expert, who is extremely generous with his time and plant materials. Arlen's wit and personal warmth, make everyone look eagerly forward to his next visit". I can personally add that most of what I claim to have figured out about blueberry genetics, I really learned from Arlen.

The following quote from Arlen (1995) is a wonderfulillumination of theman, and abeautiful description of what plant breeding is all about. "In the search for the perfect blueberry variety we sorted through hundreds of thousands of seedlings grown from thousands of crosses producing thousands of selections. Ithas truthfullybeen said that you must kiss a lot of frogs in order to find the prince. There were moments of inspiration along the way when I was prepared to receive them, usually coming during sleepless nights or early in the morning. Some of the perfect crosses that I dreamed up on my own usually proved to be something less than perfect. I have often been frustrated by failing to find the perfect variety. But now I am beginning to realize that it was the search that was important, more so than the finding. I thrilled with the hope when walking seedling rows that a world-beater was just a few plants ahead or perhaps in the next row. This is not unlike the old prospector looking for gold and always hoping to make that big strike just over the next hill."

The worldwide blueberry industry has benefited greatly from the work of the three giants described herein, Coville, Darrow, and Draper. They all displayed uncommon dedication and ingenuity. It can be said that the most successful breeders are those that stand on the shoulders of their predecessors, and polish the gems handed up to them. On the shoulders of these three pioneers, we blueberry breeders have the opportunity to reach uncommon heights.

\section{Literature Cited}

Darrow, G. M. 1966. Blueberry research. Proceedings of the North American Blueberry Workers Conference, University of Maine, Orono.

Draper,A. D. 1995. In search of the perfect blueberry variety. J. Small Fruit and Viticulture 3:17-20.

Hancock, J.F. and G.J. Galletta. 1995. Dedication: Arlen D. Draper: Blueberry Wizard. Plant Breed. Rev. 13:1-10.

Kearney, T.H. 1937. Yearbook of agriculture, p. 560. USDA, Wash., D.C

Magness, J.R. 1975. Dedication: George McMillan Darrow. In: J. Janick and J.N. Moore (eds.). Advances in fruit breeding. Purdue Univ. Press, West Lafayette, Ind.

Mainland, C.M. 1998. Frederick Coville's pioneering contributions to blueberry culture and breeding. Proc. N. Amer. Blueberry Workers Conf., Wilmington, N.C. 